\title{
Energy and water balance measurements for water productivity analysis in irrigated mango trees, Northeast Brazil
}

\author{
A.H. de C. Teixeira ${ }^{a, *}$, W.G.M. Bastiaanssen ${ }^{b, c}$, M.S.B. Moura ${ }^{a}$, \\ J.M. Soares ${ }^{a}$, M.D. Ahmad ${ }^{d}$, M.G. Bos ${ }^{e}$ \\ a Embrapa Semi-Árido, PO Box 23, 56302-970 Petrolina, PE, Brazil \\ ${ }^{\mathrm{b}}$ WaterWatch, General Foulkesweg 28, 6703 BS Wageningen, The Netherlands \\ ${ }^{\mathrm{c}}$ Delft University of Technology, Faculty of Civil Engineering and Geosciences, Stevingweg 1, 2628 CN, Delft, The Netherlands \\ ${ }^{\mathrm{d}}$ International Water Management Institute, P.O. Box 2075 Colombo, Sri Lanka \\ ${ }^{\mathrm{e}}$ International Institute for Geo-information and Earth Observation, P.O. Box 6, 7500AA Enschede, The Netherlands
}

\section{A R T I C L E I N F O}

\section{Article history:}

Received 22 March 2007

Received in revised form

5 May 2008

Accepted 7 May 2008

Keywords:

Mango orchard

Energy balance

Water balance

Evapotranspiration

Irrigation performance

Crop water productivity

\begin{abstract}
A B S T R A C T
Crop water parameters, including actual evapotranspiration, transpiration, soil evaporation, crop coefficients, evaporative fractions, aerodynamic resistances, surface resistances and percolation fluxes were estimated in a commercial mango orchard during two growing seasons in Northeast Brazil. The actual evapotranspiration $\left(E_{\mathrm{a}}\right)$ was obtained by the eddy covariance $(E C)$ technique, while for the reference evapotranspiration $\left(E_{0}\right)$; the FAO PenmanMonteith equation was applied. The energy balance closure showed a gap of $12 \%$. For water productivity analysis the $E_{\mathrm{a}}$ was then computed with the Bowen ratio determined from the eddy covariance fluxes. The mean accumulated $E_{\mathrm{a}}$ for the two seasons was $1419 \mathrm{~mm}$ year ${ }^{-1}$, which corresponded to a daily average rate of $3.7 \mathrm{~mm}$ day $^{-1}$. The mean values of the crop coefficients based on evapotranspiration $\left(K_{\mathrm{c}}\right)$ and based on transpiration $\left(K_{\mathrm{cb}}\right)$ were 0.91 and 0.73 , respectively. The single layer $K_{c}$ was fitted with a degree days function. Twenty percent of evapotranspiration originated from direct soil evaporation. The evaporative fraction was 0.83 on average. The average relative water supply was 1.1, revealing that, in general, irrigation water supply was in good harmony with the crop water requirements. The resulting evapotranspiration deficit was 73-95 mm per season only. The mean aerodynamic resistance $\left(r_{\mathrm{a}}\right)$ was $37 \mathrm{~s} \mathrm{~m}^{-1}$ and the bulk surface resistance $\left(r_{\mathrm{s}}\right)$ was $135 \mathrm{~s} \mathrm{~m}^{-1}$. The mean unit yield was 45 tonne ha ${ }^{-1}$ being equivalent to a crop water productivity of $3.2 \mathrm{~kg} \mathrm{~m}^{-3}$ when based on $E_{\mathrm{a}}$ with an economic counterpart of US $\$ 3.27 \mathrm{~m}^{-3}$. The drawback of this highly productive use of water resources is an unavoidable percolation flux of approximately $300 \mathrm{~mm}$ per growing season that is detrimental to the downstream environment and water users.
\end{abstract}

(C) 2008 Elsevier B.V. All rights reserved.

\section{Introduction}

Fruit crops in the semi-arid region of the São Francisco River basin in Brazil constitute an important activity for the livelihoods of rural communities. Mango is important for export markets. Its fruit has the advantage of being juicy and relatively large in size, besides being a rich nutrient source. The global large mango players are India (50\%), China (9\%),

\footnotetext{
* Corresponding author. Tel.: +55 87 38621711; fax: +55 8738621744.

E-mail addresses: heribert@cpatsa.embrapa.br (A.H. de C. Teixeira), W.Bastiaanssen@waterwatch.nl (W.G.M. Bastiaanssen), magna@cpatsa.embrapa.br (M.S.B. Moura), monteiro@cpatsa.embrapa.br (J.M. Soares), A.Mobin@CGIAR.ORG (M.D. Ahmad), bos@itc.nl (M.G. Bos). 0168-1923/\$ - see front matter (C) 2008 Elsevier B.V. All rights reserved. doi:10.1016/j.agrformet.2008.05.004
} 
Mexico (6\%), Thailand (5\%), Philippines (5\%) and Pakistan (4\%). Brazil has $2.5 \%$ of the world production, and after Mexico is the second largest mango producing country in the Americas.

Mango is a perennial crop with a high leaf area index and a relative deep rooting depth from 100 to $150 \mathrm{~cm}$. The trees basically require a frost-free climate and grow most favourably in warm climates $\left(25-35^{\circ} \mathrm{C}\right)$, in almost any well-drained soil whether sandy, loam or clay. Experience indicates that the water use of fruit crops varies considerably; it is unknown how much variability exists from orchard to orchard. Differences in cultivation practices or the method used in calculating evapotranspiration are of fundamental importance for extrapolation of research results to other regions (Williams and Ayars, 2005).

The relationship between irrigation, evapotranspiration, yield and percolation is essential for applying and maintaining good water management practices. The agro-hydrological processes in a mango orchard are only rarely described in the international literature. Despite the economical and nutritious importance of its fruits, little research has been attributed to the crop water productivity $\left(C_{\mathrm{WP}}\right)$. The index $\mathrm{C}_{\mathrm{PW}}$ can have a variety of definitions. The most common are: the fresh fruit productivity in terms of actual evapotranspiration or actual transpiration and in terms of the volume of applied irrigation water (Molden et al., 2003). It can also be expressed in terms of monetary value per unit of water (Bos et al., 2005).

$E_{\mathrm{a}}$ measurements by energy balance techniques in tropical fruits, vineyards and vegetables have been made in grapes (Heilman et al., 1996), mango orchard (Azevedo et al., 2003), garlic (Vilalolobos et al., 2004), grapes (Yunusa and Walker, 2004), pecans (Sammis et al., 2004), citrus (Rana et al., 2005), peach (Paço et al., 2006), olives (Testi et al., 2006) and grapes (Teixeira et al., 2007).

Irrigation of mango orchards can be associated with environmental problems. Molle et al. (1999) reported that mango orchards in Thailand are receiving 20 pesticide treatments and 5 fertilizer applications per season. Despite growing attention in irrigated orchards to leaking root zones, in general during the last decades, knowledge on evapotranspiration-percolation relationships is nevertheless limited. Thus the environmental impact of non-consumed irrigation water requires more attention. This paper addresses $E_{a}$ measurements which, in conjunction with soil moisture storage changes, and rainfall, allow the isolation of percolation fluxes (instead of deriving $E_{\mathrm{a}}$ from percolation estimates, we assess percolation from $E_{\mathrm{a}}$ estimates).

The general objective of this study was to find useful recommendations for a rational and strategic water management in irrigated mango orchards. The specific objectives of this study are

- The evaluation of the performance of the eddy covariance technique for measuring actual evapotranspiration for tropical fruits.

- Assessment of daily and seasonal mango evapotranspiration and related crop water parameters for two complete growing seasons having different rainfall regimes.

- Determination of the field scale water balance for irrigation performance and environmental analysis.
- Quantifying water productivity indicators at field scale that can be used in subsequent up scaling studies.

\section{Materials and methods}

\subsection{Measurement site}

This study was carried out from 2003 to 2005, in a mango orchard located in the semi-arid region of the São Francisco River basin, Northeast Brazil. This area in Pernambuco State has a mean total annual precipitation of $570 \mathrm{~mm}$ and a corresponding mean pan evaporation of $2700 \mathrm{~mm}$ at a mean air temperature of $26.5^{\circ} \mathrm{C}$. The orchard is located in Fruitfort farm, Petrolina, latitude $09^{\circ} 22^{\prime} \mathrm{S}$, longitude $40^{\circ} 34^{\prime} \mathrm{W}$, Pernambuco state, Brazil. The cv. is Tommy Atkins, 18 years old (in 2003), spaced in a regular square pattern at $10 \mathrm{~m} \times 10 \mathrm{~m}$, with an average height of $5.5 \mathrm{~m}$, mean leaf area index (LAI) of 5.6 and daily micro-sprinkler irrigation of an area of 11.92 ha (see Fig. 1 for a location view), with one in-line micro sprinkler between two trees on the ground at a discharge rate of $44 \mathrm{~L} \mathrm{~h}^{-1}$ which wetted $70 \%$ of the soil surface. The irrigation requirements were calculated based on reference evapotranspiration and crop coefficients adapted from published values for citrus, according to different crop stages. The orchard is bordered on all sides by other mango crops with similar height. The sensors were installed at the centre of the plot. There is no cover crop. The sandy soil is classified as Latossoil Red-Yellow with low retention capacity. The groundwater depth is approximately $2.5 \mathrm{~m}$, and the farm is located $5.5 \mathrm{~km}$ away from the São Francisco River.

A mango growth cycle extends from November to October. The fruit trees undergo vegetative growth between November and January, followed by branch development from January to May. The mango trees in the region flower typically in May to July, with fruit initiation in June and July. Fruit growth occurs in July and August. Fruit maturation typically occurs during August and September. The fruits are then picked during September and October. Healthy trees require little pruning. Besides irrigating the crop with a water depth of approximately $900 \mathrm{~mm}$, farmers spray pesticides on a weekly basis for crop protection. Fertilizers are applied through the microsprinkler irrigation system. Mango trees require regular applications of nitrogen fertilizer to promote healthy growth flushes and flower production, and the NPK application depends on soil and leaf analysis. Heck et al. (2003) reported a fertilizer application in the same region of Pernambuco of 2.5 tonne ha $\mathrm{h}^{-1}$ of dolomite lime and $20 \mathrm{~L}$ per tree of goat manure.

The study comprised two growing seasons. The duration of the first period was 390 days, from 01 October 2003 (Day 274) to 24 October 2004 (Day 298). The measurements continued into a second period of 370 days, elapsing from 25 November 2004 (Day 299) to 29 November 2005 (Day 302).

\subsection{Orchard energy balance}

During the experiments, all components of the energy balance were acquired by both, the Bowen ratio and eddy covariance methods (Fig. 1), but only eddy covariance measurements were used for the partition of the heat fluxes in this paper. 


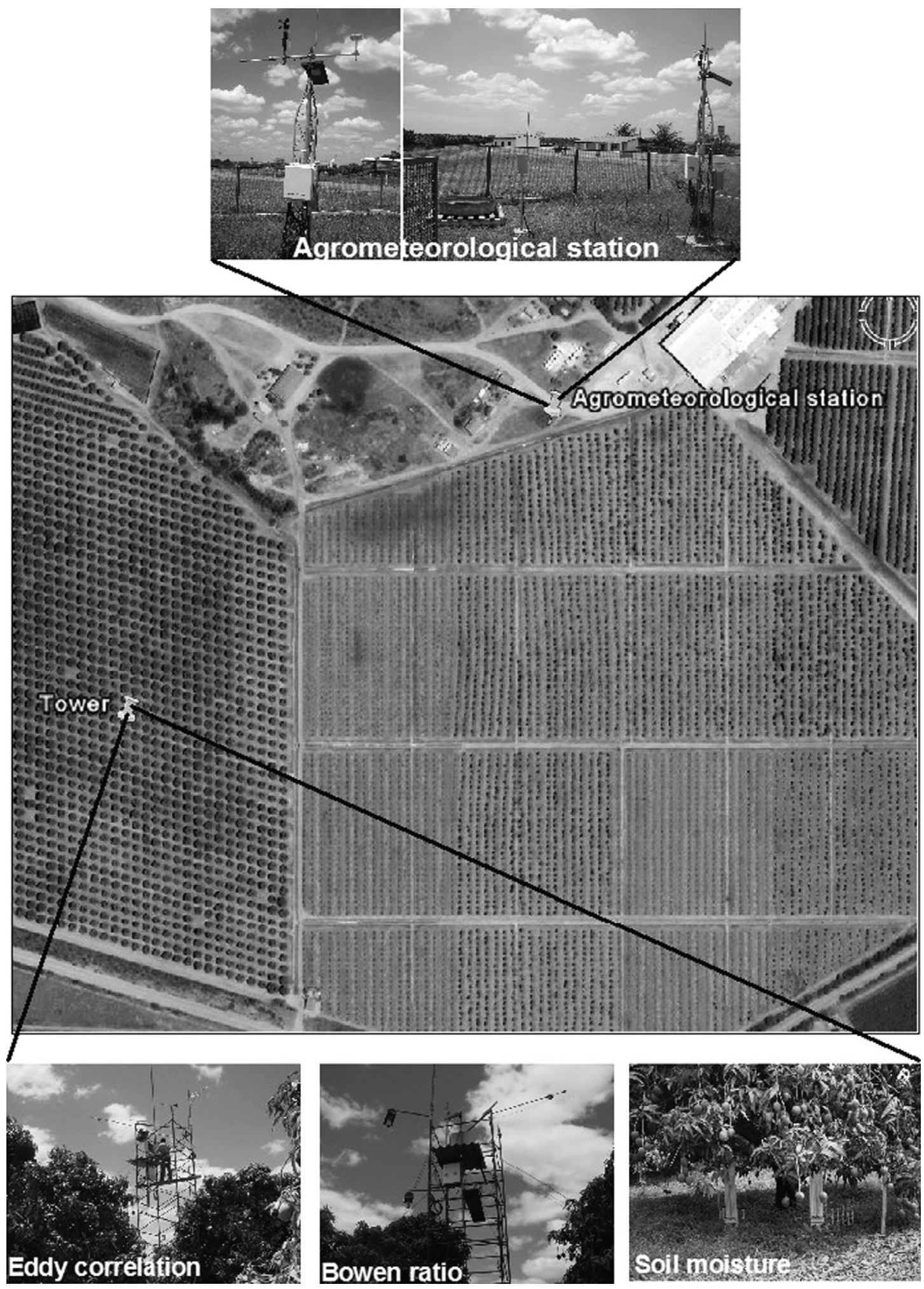

Fig. 1 - Location of the experimental mango flux site in the Low-Middle São Francisco river basin, Northeast Brazil.

The eddy covariance system determined the sensible $(H)$ and latent heat fluxes $(\lambda E)$ using a three-axis sonic anemometer (Model CSAT3, Campbell Scientific, Logan, UT, USA) and a krypton hygrometer (Model KH2O, Campbell Scientific,
Logan, UT, USA), respectively, connected to a datalogger (model CR10X, Campbell Scientific, Logan, UT, USA). The sensors were installed at a height of $8.5 \mathrm{~m}$ (thus $3 \mathrm{~m}$ above the crown of the mango tree) with a horizontal separation of 
$0.15 \mathrm{~m}$ and with a sampling frequency of $16 \mathrm{~Hz}$. Corrections to the $\lambda E$ due to sensible and latent flux (Webb et al., 1980), oxygen absorption (Tanner et al., 1993) and frequency losses (Moore, 1986) were applied using software developed by Van Dijk et al. (2004). The fluxes were computed for 30 min periods and later summed to give daily totals.

The net radiation $\left(R_{n}\right)$ was acquired with one net radiometer (model NR-Lite, Kipp \& Zonnen, Delft, The Netherlands) above a row of plants at a height of $7.5 \mathrm{~m}$. Previous experiments with fruit crops have shown that no big differences arise by using one sensor or two above and between rows for determination of $R_{n}$ at this height (Teixeira et al., 2007). The soil heat flux (G) was measured with two heat flux plates (model HFT3-L, REBS, Radiation and Energy Balance Systems, Seattle, WA, USA) at $2 \mathrm{~cm}$ soil depth and below the projected tree crown at $100 \mathrm{~cm}$ from the trunk. Flux plates were buried one at the west and the other at the east side a row of trees. The values of $G$ were obtained as the average of the two measurements. $R_{n}$ and $G$ were measured at each $5 \mathrm{~s}$ interval and $10 \mathrm{~min}$ averages were stored on another datalogger (the same model used for eddy covariance measurements).

Missing data for $\lambda E$ from krypton hygrometer during the rainy periods were estimated by the relationship between $(H+\lambda E)$ and the available energy $\left(R_{n}+G\right)$. After gap filling, the complete energy and water balances for entire growing seasons could be derived. The tower did not have problems of fetch in any direction, as the plot of 11.92 ha was inside a big farm with around 140 ha of mango orchards, southeast is the predominant wind direction.

Because of the lack of energy closure, a hybrid combination of radiation and flux measurements was deployed in this study. This combination method using eddy covariance measurements and the Bowen ratio of the fluxes $(\beta=H / \lambda E)$, the latent heat flux $(\lambda E)$ was derived using the following equation:

$\lambda E=\frac{R_{\mathrm{n}}-\mathrm{G}}{1+\beta}$

The actual evapotranspiration $\left(E_{\mathrm{a}}\right)$ was calculated transforming the $\lambda E$ into millimetres of water. The calculation of $E_{a}$ at a daily time scale was obtained by summation of all $30 \mathrm{~min}$ values for $24 \mathrm{~h}$ periods.

\subsection{Evapotranspiration and crop coefficients}

The reference evapotranspiration $\left(E_{0}\right)$ was calculated from Allen et al. (1998) using climatic data from an agro-meteorological station in the vicinity of the orchard $(500 \mathrm{~m})$. Half hourly measurements of average air temperature, relative humidity, wind speed, net radiation over grass and soil heat flux were used. The crop coefficient $\left(K_{\mathrm{c}}\right)$ was expressed as $E_{\mathrm{a}} /$ $E_{0}$. The upper envelope of the $K_{c}$ values was used to derive potential evapotranspiration $\left(E_{\mathrm{p}}\right)$. For the evaluation of actual transpiration $\left(T_{\mathrm{a}}\right)$ and soil evaporation $\left(E_{\mathrm{s}}\right), K_{\mathrm{c}}$ was separated into two components: $K_{\mathrm{cb}}$ (basal coefficient) and $K_{\mathrm{e}}$ (soil evaporation component), respectively, using daily fluctuations of $K_{c}$. Minimum values of this last coefficient were used to fit a curve for obtaining daily $K_{c b}$ values, while $K_{e}$ was considered as the difference between $K_{c}$ and $K_{c b}$. Hence

$\mathrm{T}_{\mathrm{a}}=K_{\mathrm{cb}} E_{0}$

$E_{\mathrm{s}}=K_{\mathrm{e}} E_{0}$

\subsection{Additional measurements}

The soil moisture was monitored weekly in the orchard with tensiometers at depths of 20,40,60,80,100 and $120 \mathrm{~cm}$. These depths are considered to be inside the effective root zone for mango trees under local conditions. Suctions were converted into soil moisture by using measured soil water retention curves.

Microclimatic data of air temperature and relative humidity were used together with $R_{\mathrm{n}}, \lambda E$ and $G$ to estimate the bulk surface resistance to water vapour transport $\left(r_{\mathrm{s}}\right)$ applying the Penman-Monteith equation:

$\lambda E=\frac{\Delta\left(R_{\mathrm{n}}-G_{0}\right)+\rho_{\mathrm{a}} c_{\mathrm{p}} D / r_{\mathrm{a}}}{\Delta+\gamma\left(1+r_{\mathrm{s}} / r_{\mathrm{a}}\right)}$

where $\Delta\left(\mathrm{kPa}^{\circ} \mathrm{C}^{-1}\right)$ is the slope of the saturated vapour pressure curve, $\rho_{\mathrm{a}}\left(\mathrm{kg} \mathrm{m}^{-3}\right)$ is the air density, $c_{\mathrm{p}}\left(\mathrm{J} \mathrm{kg}^{-1} \mathrm{~K}^{-1}\right)$ is the air specific heat at constant pressure, $\mathrm{D}(\mathrm{kPa})$ is the vapour pressure deficit and $\gamma\left(\mathrm{kPa}{ }^{\circ} \mathrm{C}^{-1}\right)$ is the psychrometric constant. The value of $r_{\mathrm{s}}$ is obtained from model inversion of this equation using $30 \mathrm{~min}$ data. The $30 \mathrm{~min}$ data values of $r_{\mathrm{s}}$ were averaged.

The aerodynamic resistance $r_{\mathrm{a}}\left(\mathrm{s} \mathrm{m}^{-1}\right)$ was estimated using flux profile relationships. In this method the atmospheric surface layer similarity theory was used, applying the universal functions suggested by Businger et al. (1971) and the integrated stability functions of temperature $\left(\Psi_{\mathrm{h}}\right)$ and momentum $\left(\Psi_{\mathrm{m}}\right)$.

\subsection{Soil water balance and storage change}

The combined percolation and drainage term can be obtained from the remaining soil water balance terms as the difference between inputs (precipitation $P$, irrigation $I$ and change in moisture storage, $\Delta W$ ) and outputs $\left(E_{\mathrm{a}}\right)$. Since sub-surface drainage systems were absent, and flow to surface drains is negligible, the combined percolation/drainage flux can essentially be considered to represent deep percolation $D_{\mathrm{P}}$ :

$D_{\mathrm{P}}=\mathrm{P}+\mathrm{I}-\mathrm{E}_{\mathrm{a}} \pm \Delta \mathrm{W}$

The changes in soil water storage $(\Delta \mathrm{W})$ are positive when water is added to the root zone, otherwise it is negative:

$\Delta \mathrm{W}=\mathrm{W}(\mathrm{t}-1)-\mathrm{W}(\mathrm{t})$

The water storage $\mathrm{W}$ in the root zone is derived from the layer-wise soil moisture values $\left(\theta_{i}\right)$. At moment $t$, the storage across the depth $\left(\delta z_{i}\right)$ of the six sensors $(i=1, \ldots, 6)$ can be computed as

$\mathrm{W}(\mathrm{t})=\delta \mathbf{z}_{1} \theta_{1}+\delta \mathbf{z}_{2} \theta_{2}+\delta \mathbf{z}_{3} \theta_{3}+\delta \mathbf{z}_{4} \theta_{4}+\delta \mathbf{z}_{5} \theta_{5}+\delta \mathbf{z}_{6} \theta_{6}$ 


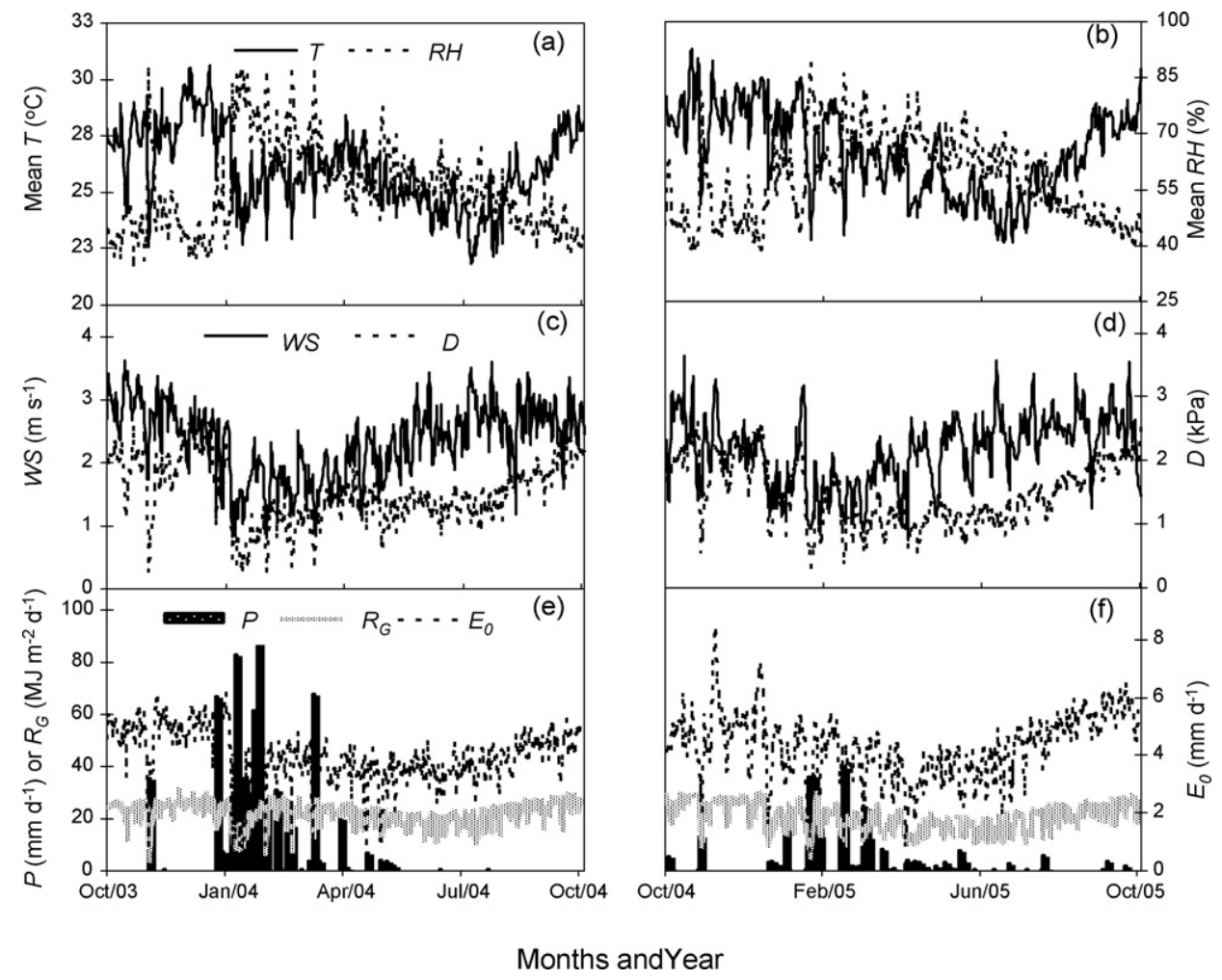

Fig. 2 - Daily values of weather variables during the study period from 2003 to 2005. (a and b) Mean air temperature (T) and relative humidity (RH); (c and d) wind speed (WS) and water vapor pressure deficit (D); (e and f) solar radiation ( $\left.R_{G}\right)$, reference evapotranspiration $\left(E_{0}\right)$ and precipitation $(P)$.

\subsection{Irrigation performance and crop water productivity}

Following Bastiaanssen et al. (2001) the irrigation performance indicators applied in this study were the relative water supply $\left(R_{\mathrm{WS}}\right)$, crop water deficit ( $\left.C_{\mathrm{WD}}\right)$ and crop water productivity $\left(C_{\mathrm{WP}}\right)$ based on irrigation $(I)$, actual evapotranspiration $\left(E_{\mathrm{a}}\right)$, actual transpiration $\left(\mathrm{T}_{\mathrm{a}}\right)$ and actual crop yield $\left(\mathrm{Y}_{\mathrm{a}}\right)$ :

$R_{\mathrm{WS}}=\frac{\mathrm{V}_{\mathrm{I}}+P}{E_{\mathrm{p}}}$

$C_{W D}=E_{p}-E_{a}$

$C_{W P}=\frac{Y_{a}}{V_{E_{a}, T_{a}, I}}$

where $P$ is the precipitation; $V_{I}$ the water applied through irrigation; $V_{E_{a}}$ and $V_{T_{a}}$ are water fluxes by actual evapotranspiration and actual transpiration, respectively; and $\mathrm{Y}_{\mathrm{a}}$ is the actual yield of fruits.

Increases in economic water productivity may indicate a shift towards higher valued crops, increase in yields or a saving in water input (Bos et al., 2005). As economic indicators, the indexes used were the standard gross value of production (fruits) over the irrigation supply (CWP\$I) and over actual evapotranspiration or actual transpiration (CWP $\left.\$_{E_{a}, T_{a}}\right)$.

\section{Results}

\subsection{Weather conditions and soil moisture}

Fig. 2 shows the daily averaged weather variables during the two growing seasons studied. Air temperature $(T)$ reached the maximum value in November and December with approximately $30^{\circ} \mathrm{C}$, while the minimum values occurred during June $\left(22^{\circ} \mathrm{C}\right)$. The relative humidity $(\mathrm{RH})$ presented the inverse behaviour. The values for vapour pressure deficit $(D)$, calculated for each half hour and averaged for $24 \mathrm{~h}-$ which expresses the inverse of $\mathrm{RH}$ - presented the same temporal behaviour as air temperature through the growing seasons. Wind speed (WS) at $3 \mathrm{~m}$ above a standardized grass field presented maximum values from July to November $\left(3.6 \mathrm{~m} \mathrm{~s}^{-1}\right)$ and the minimum values from January to April $\left(0.8 \mathrm{~m} \mathrm{~s}^{-1}\right)$. The wind speed over the rough mango trees were around $12 \%$ greater than over grass due to the height of the anemometer above the orchard. Values of global radiation $\left(R_{G}\right)$ were as expected in the southern hemisphere: lower from April to July and higher from August to January, when they started to decline again. Reference evapotranspiration $\left(E_{0}\right)$ followed the oscillation of $R_{\mathrm{G}}$. Precipitation was concentrated between January and April. The year 2004 was unusually wet. The accumulated rainfall for the first growing season was $887 \mathrm{~mm}$, for the second it was only $384 \mathrm{~mm}$, while the longer term annual average is $570 \mathrm{~mm}$. 


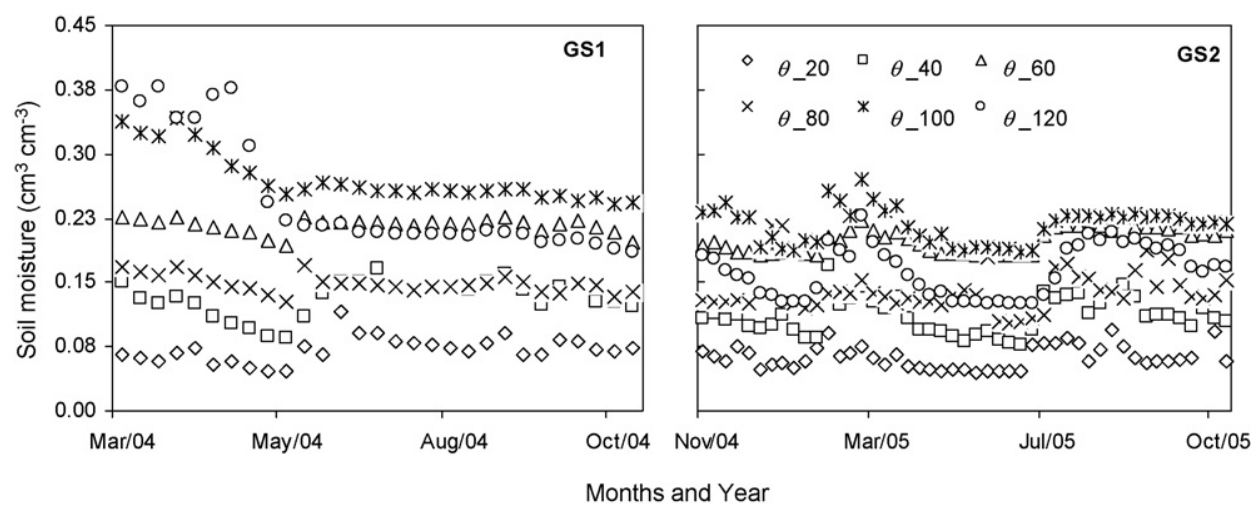

Fig. 3 - Soil water content $\left(\theta_{i}\right)$ at different depths $(i=20 \mathrm{~cm}, i=40 \mathrm{~cm}, i=60 \mathrm{~cm}, i=80 \mathrm{~cm}, i=100 \mathrm{~cm}, i=120 \mathrm{~cm})$ during the first (a) and second (b) growing seasons of mango orchard.

The values of layer-wise soil water content $(\theta)$ from 20 to $120 \mathrm{~cm}$ depth are presented in Fig. 3. The near-surface moisture content values were from 0.04 to $0.12 \mathrm{~cm}^{3} \mathrm{~cm}^{-3}$ only, which creates a visually dry soil surface. Underneath the dry surface layer, the soil was wet with measured $\theta$ values peaking at $0.38 \mathrm{~cm}^{3} \mathrm{~cm}^{-3}$. These levels can be interpreted as representing the soil porosity when the volumetric soil water content reaches its maximum in sandy soil. The highest moisture values occurred at the end of February in 2004 and are related to the preceding storm events. After this period, soil moisture was approximately constant throughout the seasons. The values at $120 \mathrm{~cm}$ were most often lower than at 60 and $100 \mathrm{~cm}$, which reveal typical downward percolation conditions. The magnitude of the percolation needs to be investigated from the soil water balance. As the effective root zone of mango crop is $120 \mathrm{~cm}$, it can be concluded from the $\theta$ values that the mango orchard was not stressed by water shortage during most of the days.

\subsection{Energy balance closure}

Despite eddy covariance being among the most advanced "in situ" measurement technologies that directly provide $\lambda E$, it is widely known to have problems. The $\lambda E$ data quality from this system has been verified by studying the energy balance closure: fluxes $(\lambda E+H)$ and available energy $\left(R_{n}-G\right)$ were compared for the whole period of measurements (2003-2005) at a daily time scale (Fig. 4). Since the main objective of the research is irrigation management and water productivities, we are less interested in studying hourly energy balance closures, daily total values are sufficient. The energy balance ratio, i.e. the ratio of turbulent energy fluxes to available energy was $88 \%$. The RMSE for $24 \mathrm{~h}$ values was $1.7 \mathrm{MJ} \mathrm{m}^{-2} \mathrm{day}^{-1}$, evidence of the good quality of the dataset.

A closure error of $10-30 \%$ seems to occur frequently with eddy covariance-based latent heat flux estimates. A summary paper of 22 flux sites indicated a general lack of closure, with a mean imbalance in the order of $20 \%$ (Wilson et al., 2002). Available energy $\left(R_{n}-G\right)$ systematically exceeding measured fluxes $(\lambda E+H)$ were also published by Twine et al. (2000), Paço et al. (2006) and Testi et al. (2006).
The lack of energy balance closure can also be associated with measurement errors in $R_{n}$ and $G$, but not completely explained by this uncertainty, because eddy covariance systems have their own sources of error (Twine et al., 2000). Further to systematic biases in the instrumentation, the general hypothesis is that lack of energy balance closure can be explained by sampling errors related to different footprints, neglected energy sinks, loss of low and/or high frequency contributions to the turbulent heat flux and advection of scalars (e.g. Paw et al., 2000).

To circumvent this common problem, several agrometeorological studies have found a practical solution to force the closure of the surface energy balance. Simmons et al. (2007) also used the residual method to obtain $E_{\mathrm{a}}$ by measuring $\mathrm{H}$ with a sonic anemometer and the available energy in a floodirrigated pecan orchard, while Chehbouni et al. (2006) used eddy covariance measurements and the ratio $H / \lambda E$ over irrigated wheat in the Yaqui Valley in northwest Mexico. It was decided to analyse the results combining the ratio $H / \lambda E$

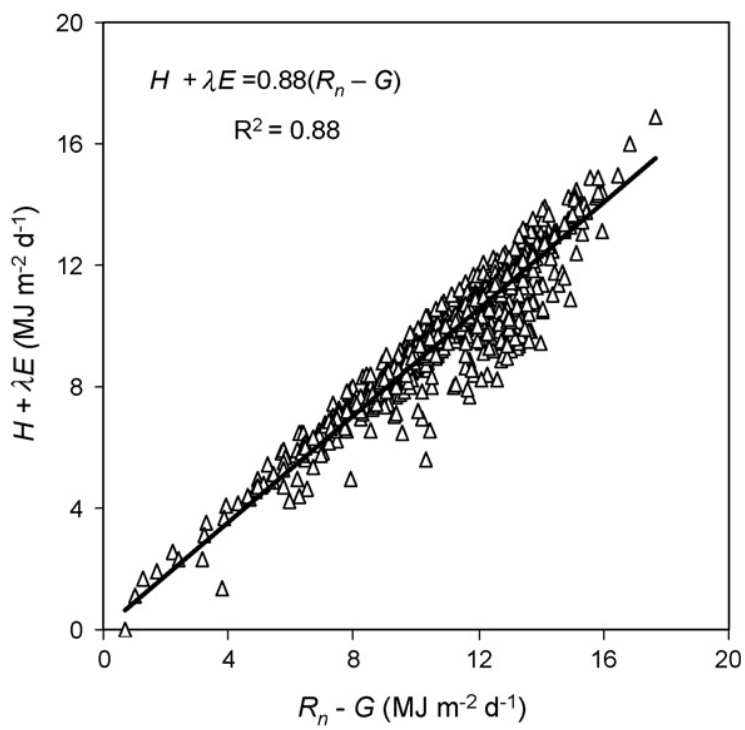

Fig. 4 - Relationship between latent heat $(\lambda E)$ plus sensible heat $(H)$ fluxes and available energy $\left(R_{n}-G\right)$ for the eddy covariance system. 


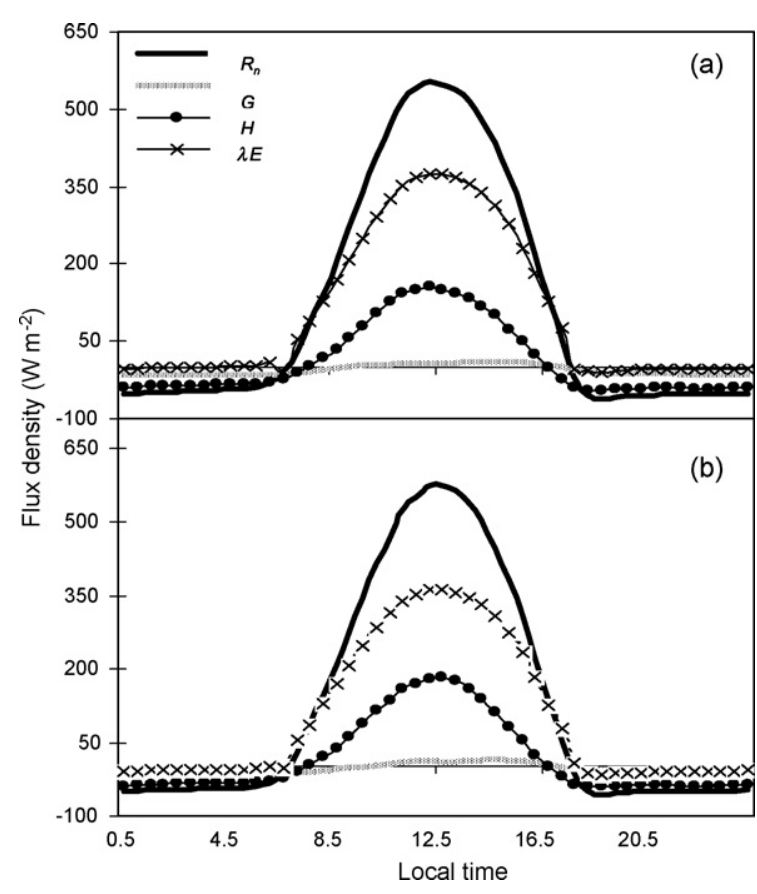

Fig. 5 - Diurnal averages for energy balance components during the growing seasons of 2003-2004 (a) and 20042005 (b) for mango orchard: net radiation $\left(R_{n}\right)$; latent heat flux $(\lambda E)$; sensible heat flux $(H)$ and soil heat flux $(G)$.

with the measured available energy (e.g. Twine et al., 2000). Whilst the lack of energy balance closure underestimates $\lambda E$, forcing the closure by this combination method we assume this underestimation to be corrected (e.g. Hoedjes et al., 2002).

The authors have a preference for the combination method because:

- it directly produces evaporative fraction, being a key expression for energy partitioning;

- it ensures a closed energy balance;

- it mainly utilizes highly advanced eddy covariance systems;

- it has a good consistency with the theoretically best $\lambda E$ measurements.

All the energy balance and $E_{\mathrm{a}}$ data discussed hereafter are based on the combination method with $H / \lambda E$ from eddy covariance measurements.

\subsection{Partition into sensible and latent heat fluxes}

Fig. $5 \mathrm{a}$ and $\mathrm{b}$ shows the diurnal trend in the fluxes of individual components of the energy balance for the mango orchard. The latent heat flux $(\lambda E)$ was always in excess of the sensible heat flux $(H)$ during daylight hours. The $H$ was - in turn - higher than the soil heat flux $(G)$. At night the results from eddy covariance (EC) showed zero latent heat flux.

Daily averages of energy balances are given in Table 1. Unstable atmospheric conditions predominated above the orchard, with the sensible heat flux $(H)$ accounting for $11 \%$ and $15 \%$ of $R_{n}$ during the first and second growing seasons, respectively. The significant leaf area index of mango crop (LAI $\sim 5$ to 6 ) caused solar radiation to hardly penetrate through the canopy. As a consequence, the soil heat flux $(G)$ at daily scale was small and negative with $24 \mathrm{~h}$ averaged values of $3 \%$ and $2 \%$ of $R_{n}$ in the first and second growing seasons, respectively. Negative values for $G$ could be the result of conditions with a large LAI in conjunction with frequent micro sprinkler irrigation that keeps the soil thermal conductivity high.

The largest part of $R_{n}$ was used as latent heat flux $(\lambda E) . \lambda E$ represented on average $89 \%$ of $R_{n}$ during the first growing season and $80 \%$ for the second one. The corresponding evaporative fractions $\left(E_{F}=\lambda E / R_{n}-G\right)$ were 0.86 and 0.79 . During an earlier mango energy balance study during 1998, the $E_{F}$ was found to be 0.73 in August, 0.86 in September, 0.78 in October and 0.80 during November (Lopes et al., 2001), similar to our results.

The values of $E_{F}$ remained rather constant during the growing seasons, which reflect a constant supply of irrigation water. An average $E_{\mathrm{F}}$ of 0.83 is according to Scott et al. (2003) equivalent to a degree of soil moisture saturation in the root zone of $67 \%$, which at a maximum moisture value of $0.38 \mathrm{~cm}^{3} \mathrm{~cm}^{-3}$ suggests average soil moisture in the root zone of $0.25 \mathrm{~cm}^{3} \mathrm{~cm}^{-3}$. The latter can be confirmed from the soil moisture measurements (see Fig. 3). Testi et al. (2004) studied the partition of energy balance in a young olive orchard, under different soil water conditions. They also concluded that the amount of $R_{n}$ used as $\lambda E$ and $H$ depends on soil water content. The rainy period elapsed from January to April and after that, farmers refrain from irrigation, inducing a drop of evaporative fraction to a value around 0.70 during the branch development stages.

\subsection{Evapotranspiration}

Despite the first growing season having an above average rainfall; the difference in potential evapotranspiration $\left(E_{p}\right)$ is mainly caused by cloud cover and solar radiation $\left(R_{G}\right)$. Outside the short rainy season, $R_{G}$ can be abundant. The $E_{p}$ in the first growing season was with $1565 \mathrm{~mm}$, more than for the second season $(1441 \mathrm{~mm})$. As a consequence of the higher potential evapotranspiration, and the wetter soil due to rainfall (the 80$120 \mathrm{~cm}$ depth layers are systematically wetter in the first growing season), actual ET in 2003-4 was $1492 \mathrm{~mm}$ and higher than the $1346 \mathrm{~mm}$ measured in 2004-05. The average $\mathrm{ET}_{\mathrm{a}}$ over the two seasons was $1419 \mathrm{~mm}$ with an average daily value rate of $3.7 \mathrm{~mm}$ day $^{-1}$.

Fig. 6 shows the seasonal trend of daily values of actual evapotranspiration $\left(E_{\mathrm{a}}\right)$ in mango orchard. The values followed the atmospheric demand in both growing seasons, being higher from October (2003) to March (2004), and from August to November (2004) in the first season, while in the second season, the peak values were from January to April and from August to November, both in 2005. Maximum daily values of $E_{a}$ for the first season were $6.3 \mathrm{~mm} \mathrm{day}^{-1}$. During the second season the maximum values were $5.1 \mathrm{~mm}^{-1} \mathrm{day}^{-1}$. The minimum values were around $0.6 \mathrm{~mm}$ day $^{-1}$.

Azevedo et al. (2003) showed averaged daily values of mango orchard $E_{\mathrm{a}}$ of $4.4 \mathrm{~mm} \mathrm{day}^{-1}$ for the crop stages from flowering to fruit maturation using both, Bowen ratio and soil water balance methods. It should be noted that the study of Azevedo reflects drip irrigation, while our study used micro 
Table 1 - Daily averages of the energy balance components for mango orchard during the growing seasons of 2003-2004 (GS1) and 2004-2005 (GS2): net radiation $\left(R_{n}\right)$, soil heat flux (G), latent heat $(\lambda E)$, sensible heat flux (H), and evaporative fraction $\left(E_{\mathrm{F}}\right)$

\begin{tabular}{|c|c|c|c|c|c|}
\hline DOY/year & $R_{\mathrm{n}}\left(\mathrm{MJ} \mathrm{m} \mathrm{m}^{-2}\right.$ day $\left.^{-1}\right)$ & $G\left(\mathrm{MJ} \mathrm{m}^{-2}\right.$ day $\left.^{-1}\right)$ & $\lambda E\left(\mathrm{MJ} \mathrm{m}^{-2}\right.$ day $\left.^{-1}\right)$ & $H\left(\mathrm{MJ} \mathrm{m}^{-2}\right.$ day $\left.^{-1}\right)$ & $E_{F}(-)$ \\
\hline \multicolumn{6}{|l|}{ GS1 } \\
\hline $303 / 2003$ & 9.66 & -0.13 & 8.43 & 0.80 & 0.86 \\
\hline $333 / 2003$ & 10.84 & -0.29 & 9.49 & 1.20 & 0.85 \\
\hline $363 / 2003$ & 10.64 & -0.22 & 9.13 & 1.14 & 0.84 \\
\hline $028 / 2004$ & 9.73 & -0.60 & 8.30 & 1.91 & 0.80 \\
\hline $058 / 2004$ & 12.18 & -1.41 & 10.28 & 2.93 & 0.76 \\
\hline $088 / 2004$ & 11.69 & -0.31 & 10.15 & 1.84 & 0.85 \\
\hline $118 / 2004$ & 11.96 & 0.00 & 10.46 & 1.25 & 0.87 \\
\hline $148 / 2004$ & 9.75 & -0.20 & 8.45 & 1.29 & 0.85 \\
\hline $178 / 2004$ & 8.91 & -0.37 & 8.09 & 0.74 & 0.87 \\
\hline $208 / 2004$ & 8.70 & -0.33 & 8.01 & 0.76 & 0.89 \\
\hline $238 / 2004$ & 9.71 & -0.28 & 8.49 & 1.04 & 0.85 \\
\hline $268 / 2004$ & 11.51 & -0.33 & 11.19 & -0.07 & 0.95 \\
\hline $298 / 2004$ & 12.21 & -0.38 & 11.65 & -0.24 & 0.93 \\
\hline Mean & 10.58 & -0.37 & 9.39 & 1.12 & 0.86 \\
\hline \multicolumn{6}{|l|}{ GS2 } \\
\hline $326 / 2004$ & 12.47 & -0.25 & 10.61 & 0.71 & 0.83 \\
\hline $354 / 2004$ & 12.17 & -0.15 & 10.17 & 1.19 & 0.83 \\
\hline $016 / 2005$ & 11.67 & -0.02 & 8.71 & 2.20 & 0.75 \\
\hline $044 / 2005$ & 12.13 & -0.30 & 9.37 & 2.57 & 0.75 \\
\hline $072 / 2005$ & 11.87 & -0.38 & 9.10 & 2.59 & 0.74 \\
\hline $100 / 2005$ & 12.41 & -0.44 & 9.43 & 2.90 & 0.73 \\
\hline $128 / 2005$ & 9.04 & -0.29 & 8.11 & 1.19 & 0.87 \\
\hline $156 / 2005$ & 8.78 & -0.07 & 7.85 & 0.83 & 0.89 \\
\hline $184 / 2005$ & 8.43 & -0.07 & 7.67 & 0.66 & 0.90 \\
\hline $212 / 2005$ & 10.03 & 0.25 & 8.40 & 0.49 & 0.86 \\
\hline $240 / 2005$ & 10.62 & -0.03 & 8.56 & 1.64 & 0.80 \\
\hline $268 / 2005$ & 12.04 & -0.20 & 9.14 & 2.60 & 0.75 \\
\hline $302 / 2005$ & 12.35 & -0.38 & 8.62 & 2.13 & 0.68 \\
\hline Mean & 11.08 & -0.18 & 8.90 & 1.67 & 0.79 \\
\hline
\end{tabular}

DOY: day of the year. The values were taken at 30 and 28 days intervals for GS1 and GS2, respectively.

sprinklers. The mean crop heights are similar for both studies (around $5 \mathrm{~m}$ ) and the trees were spaced $8.0 \mathrm{~m} \times 5.0 \mathrm{~m}$ in the previous study, while in the present field, trees stand in a regular square pattern at $10 \mathrm{~m} \times 10 \mathrm{~m}$. The mango orchard LAI in the first study was approximately 12-15 while the larger spacing in our study yields values of 5.2, 6.0 and 5.6, being another reason for the lower $E_{\mathrm{a}}$. Lopes et al. (2001) evaluating $E_{\mathrm{a}}$ using the Bowen ratio method for 6-year-old, drip-irrigated mango trees, found values in the range of 3.1-6.2 $\mathrm{mm}^{-1} \mathrm{day}^{-1}$ in Petrolina, Brazil. Annual mango $E_{\mathrm{a}}$ in South Africa was found by Mostert and Wantenaar (1994) to be $1197 \mathrm{~mm}$. The winter $E_{\mathrm{a}}$ was $2.2 \mathrm{~mm}$ day $^{-1}$ on average, while the summer $E_{\mathrm{a}}$ was with $4.4 \mathrm{~mm}$ day $^{-1}$ exactly double. Molle et al. (1999) reported on an annual mango plot water consumption of $1630 \mathrm{~mm}$ in a raised bed system, including crop consumptive use and evaporation from pounding water.

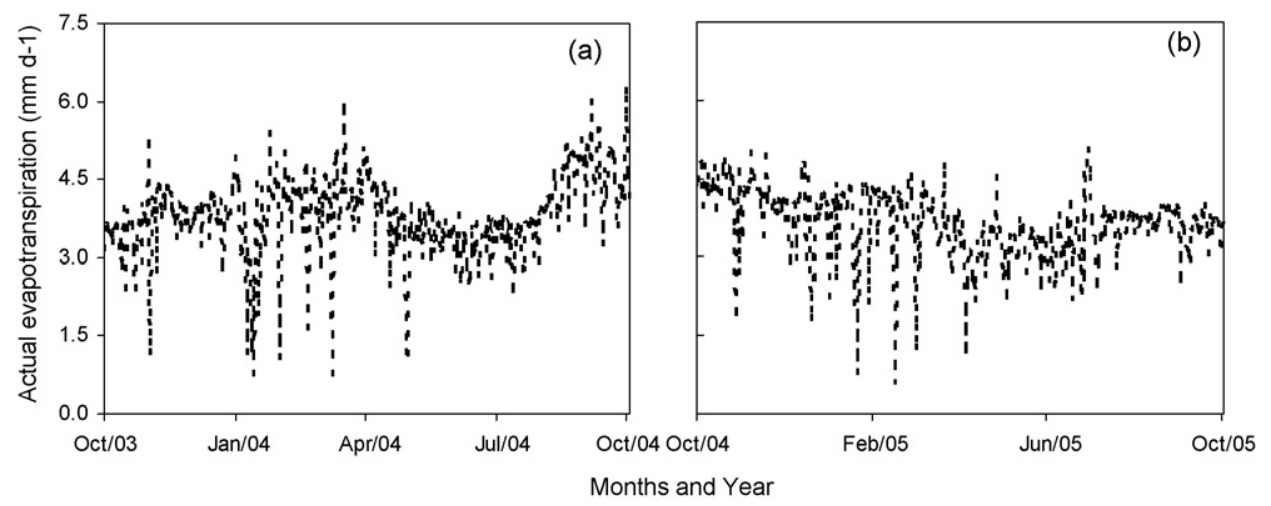

Fig. 6 - Daily variation for actual evapotranspiration, during the growing seasons of 2003-2004 (a) and 2004-2005 (b) for mango orchard, by the combination eddy covariance-Bowen ratio method. 


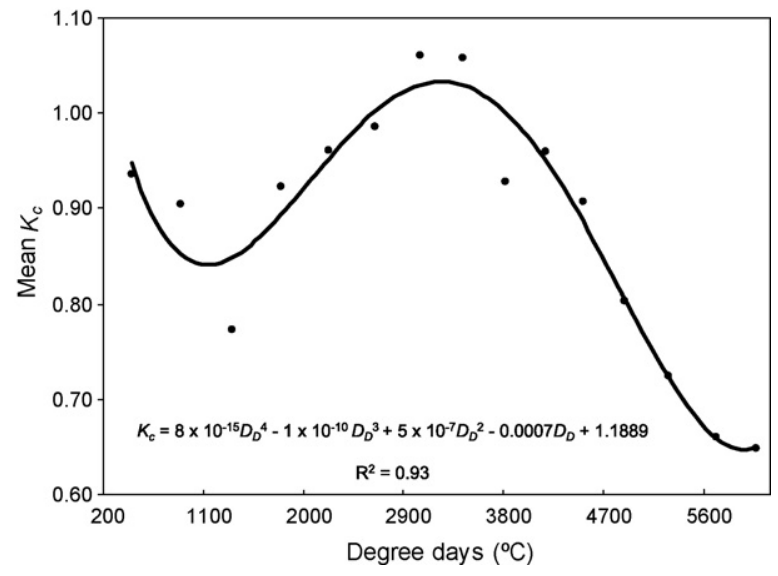

Fig. 7 - The seasonal variation of averaged daily crop coefficients (mean $K_{c}$ ), as a function of degree days, $D_{D}$ (basal $\mathrm{T}=10^{\circ} \mathrm{C}$ ), during the growing season of 2004-2005 of mango orchard, by the combination method of eddy covariance measurements with Bowen ratio.

With regard to other orchards, the $E_{\text {a }}$ results for mango were greater than for citrus (Paço et al., 2006) and lower than for peach (Rana et al., 2005). Rana et al. (2005) using eddy covariance measurement systems in a citrus orchard under Mediterranean conditions (Southern Italy) found values ranging from 3.0 to $8.0 \mathrm{~mm}$ day $^{-1}$. Paço et al. (2006) using the same method in a peach orchard in Portugal found $E_{\mathrm{a}}$ values ranging from 1.4 to $3.6 \mathrm{~mm} \mathrm{day}^{-1}$ in 1998 and from 2.1 to $3.3 \mathrm{~mm}$ day $^{-1}$ in 1999 with mean values of 2.5 and $2.6 \mathrm{~mm}^{-1}$ day $^{-1}$, respectively. The eddy covariance system was also used by Sammis et al. (2004) to study water consumption of flood-irrigated pecans in USA; they found an averaged total $E_{\mathrm{a}}$ of $1420 \mathrm{~mm}$ for 2001 and 2002 that was similar to the total $E_{\mathrm{a}}$ of mango orchard in first growing season in the present study.

\subsection{Crop coefficients}

The 20-day interval averaged $K_{c}$ data for the dry growing season (2004-2005) were fitted with a polynomial function expressed in degree days (basal $\mathrm{T}=10^{\circ} \mathrm{C}$ ) rather than in calendar days, for incorporation of temperature effects on the growing stages of mango trees (Fig. 7). The period before the pruning date was included because the farmers also applied large amounts of water during post-harvest periods, which must be included for the final water productivity analysis.

The values of $E_{a}$ largely followed the $E_{0}$. During the rainy periods at the start of the year, $E_{\mathrm{a}}$ rates exceeded $E_{0}$, resulting in daily $K_{\mathrm{c}}$ values exceeding 1 (Fig. 8). Soil evaporation plays a role in these high $K_{c}$ values, as can be seen by the high values of the crop coefficient based on soil evaporation $\left(K_{e}\right)$. This effect was more pronounced in 2004, when unusually strong storms occurred. The highest daily values of $K_{c}$ were from the end of January to end of March for both seasons reaching peak $K_{c}$ values of 1.40. This time of both years (2004 and 2005) was the rainy period when the crop was at the branch development and flowering stages. The minimum values occurred when the crop was in a transition stage from previous post-harvest to vegetative growth, coinciding with periods without rain.

For both seasons, higher $K_{c}$ values were found than by Azevedo et al. (2003) who reported $K_{c}$ values around 0.71 during the crop stages studied. They also fitted a polynomial curve, but with $K_{c}$ values as a function of the days after flowering (DAF). The higher $K_{c}$ values in our study have the same reasons as mentioned for $E_{\mathrm{a}}$, but in addition it should be noticed that they used a conventional agro-meteorological station in contrast with our automatic weather station data to calculate $E_{0}$.

The maximum $K_{c}$ values found for citrus by Rana et al. (2005) were around 1.20, a little lower than the results for mango orchard during our study, while Sammis et al. (2004) and Paço et al. (2006) found much lower values in the range of 0.20-1.10 for pecan and from 0.40 to 0.60 for peach orchards, respectively. The minimum $K_{c}$ values for 20-day periods were considered to represent the basal coefficients $\left(K_{\mathrm{cb}}\right)$ and a curve was fitted (Fig. 8). The maximum daily values of $K_{\mathrm{cb}}$ were 0.85 and 0.75 for the first and second growing seasons, respectively. The minimum values for initial stages were 0.46 during the first season. During the second season, minimum initial $K_{\mathrm{cb}}$ values were 0.41 . The basal crop coefficients during the harvest season were 0.67 and 0.36 for the first and second years, respectively. This trend was also observed in the $K_{c}$ analysis. With the difference between $K_{\mathrm{c}}$ and $K_{\mathrm{cb}}$ the resulted $K_{e}$ values showed that soil evaporation contributed about $20 \%$ to the total mango orchard $E_{\mathrm{a}}$. With values of $K_{\mathrm{cb}}, K_{\mathrm{e}}$ and $E_{0}$, the actual transpiration $\left(T_{\mathrm{a}}\right)$ and soil evaporation $\left(E_{\mathrm{s}}\right)$ could be

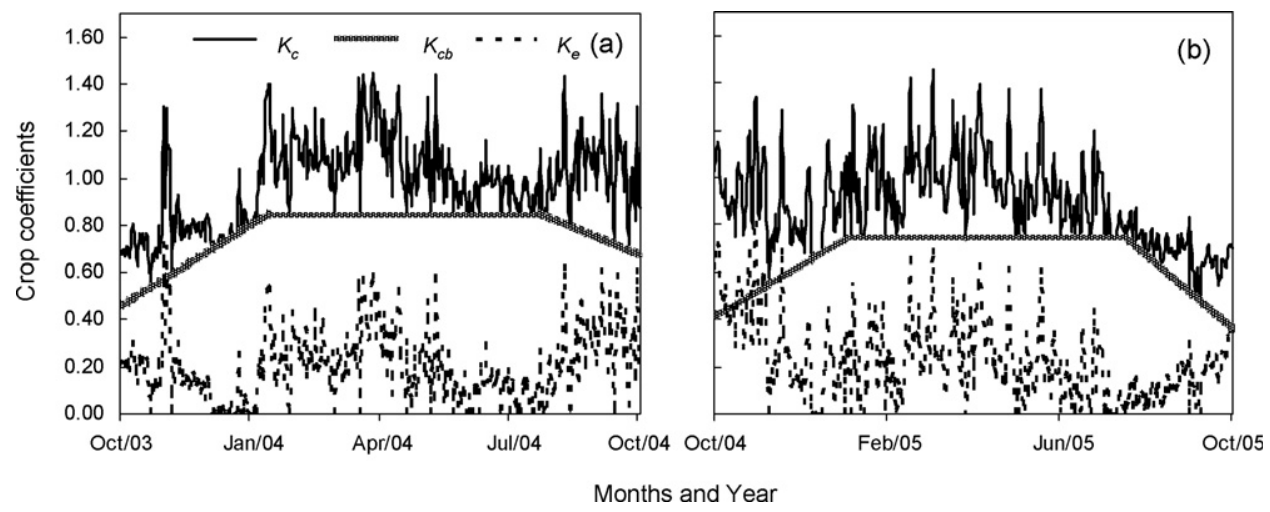

Fig. 8 - Seasonal variation of daily crop coefficients in mango orchard for the first (a) and second (b) growing seasons: crop coefficients based on evapotranspiration $\left(K_{c}\right)$, transpiration $\left(K_{c b}\right)$ and soil evaporation $\left(K_{e}\right)$. 
Table 2 - Summary of water-use variables for mango orchard during the growing seasons of 2003-2004 (GS1) and 20042005 (GS2): mean values of reference evapotranspiration $\left(E_{0}\right)$, actual evapotranspiration $\left(E_{\mathrm{a}}\right)$; actual transpiration ( $T_{\mathrm{a}}$ ) and soil evaporation $\left(E_{s}\right)$; crop factors based on evapotranspiration $\left(K_{c}\right)$, transpiration $\left(K_{c b}\right)$ and soil evaporation $\left(K_{e}\right)$; aerodynamic $\left(r_{\mathrm{a}}\right)$ and surface $\left(r_{\mathrm{s}}\right)$ resistances

\begin{tabular}{|c|c|c|c|c|c|c|c|c|c|}
\hline DOY/year & $\begin{array}{c}E_{0} \\
\left(\mathrm{~mm} \mathrm{day}^{-1}\right)\end{array}$ & $\begin{array}{c}E_{\mathrm{a}} \\
\left(\mathrm{mm} \mathrm{day}^{-1}\right)\end{array}$ & $\begin{array}{c}\mathrm{T}_{\mathrm{a}} \\
\left(\mathrm{mm} \mathrm{day}^{-1}\right)\end{array}$ & $\begin{array}{c}E_{\mathrm{s}} \\
\left(\mathrm{mm} \mathrm{day}^{-1}\right)\end{array}$ & $K_{\mathrm{c}}$ & $K_{\mathrm{cb}}$ & $K_{\mathrm{e}}$ & $\begin{array}{c}r_{\mathrm{a}} \\
\left(\mathrm{s} \mathrm{m}^{-1}\right)\end{array}$ & $\begin{array}{c}r_{\mathrm{s}} \\
\left(\mathrm{s} \mathrm{m}^{-1}\right)\end{array}$ \\
\hline \multicolumn{10}{|l|}{ GS1 } \\
\hline $303 / 2003$ & 4.87 & 3.41 & 2.49 & 0.92 & 0.70 & 0.51 & 0.19 & 32 & 191 \\
\hline $333 / 2003$ & 4.70 & 3.87 & 2.90 & 0.97 & 0.82 & 0.62 & 0.21 & 34 & 160 \\
\hline $363 / 2003$ & 4.18 & 3.79 & 3.59 & 0.20 & 0.91 & 0.72 & 0.19 & 44 & 193 \\
\hline $028 / 2004$ & 3.67 & 3.40 & 2.99 & 0.41 & 0.93 & 0.82 & 0.10 & 38 & 116 \\
\hline $058 / 2004$ & 3.82 & 4.18 & 3.24 & 0.93 & 1.09 & 0.85 & 0.24 & 44 & 107 \\
\hline $088 / 2004$ & 3.78 & 4.08 & 3.21 & 0.86 & 1.08 & 0.85 & 0.23 & 35 & 112 \\
\hline $118 / 2004$ & 3.52 & 4.24 & 3.00 & 1.25 & 1.20 & 0.85 & 0.35 & 43 & 121 \\
\hline $148 / 2004$ & 3.34 & 3.43 & 2.84 & 0.59 & 1.03 & 0.85 & 0.18 & 41 & 119 \\
\hline $178 / 2004$ & 3.56 & 3.36 & 3.03 & 0.33 & 0.94 & 0.85 & 0.09 & 31 & 135 \\
\hline $208 / 2004$ & 3.41 & 3.29 & 2.90 & 0.39 & 0.96 & 0.85 & 0.11 & 30 & 121 \\
\hline $238 / 2004$ & 3.74 & 3.49 & 3.13 & 0.35 & 0.93 & 0.84 & 0.09 & 33 & 123 \\
\hline $268 / 2004$ & 4.27 & 4.57 & 3.32 & 1.25 & 1.07 & 0.78 & 0.29 & 34 & 122 \\
\hline $298 / 2004$ & 4.44 & 4.63 & 3.14 & 1.49 & 1.04 & 0.71 & 0.34 & 34 & 145 \\
\hline Mean & 3.95 & 3.83 & 3.06 & 0.75 & 0.97 & 0.78 & 0.19 & 36 & 136 \\
\hline \multicolumn{10}{|l|}{ GS2 } \\
\hline $326 / 2004$ & 4.66 & 4.33 & 2.15 & 2.18 & 0.93 & 0.46 & 0.47 & 36 & 152 \\
\hline $354 / 2004$ & 5.02 & 4.17 & 2.82 & 1.35 & 0.83 & 0.56 & 0.27 & 36 & 155 \\
\hline $016 / 2005$ & 4.87 & 3.74 & 3.19 & 0.55 & 0.77 & 0.66 & 0.11 & 39 & 180 \\
\hline $044 / 2005$ & 4.14 & 3.78 & 3.06 & 0.72 & 0.91 & 0.74 & 0.17 & 42 & 149 \\
\hline $072 / 2005$ & 3.92 & 3.65 & 2.94 & 0.71 & 0.93 & 0.75 & 0.18 & 46 & 120 \\
\hline $100 / 2005$ & 3.74 & 3.81 & 2.81 & 1.00 & 1.02 & 0.75 & 0.27 & 46 & 111 \\
\hline $128 / 2005$ & 3.06 & 3.21 & 2.30 & 0.91 & 1.05 & 0.75 & 0.30 & 39 & 113 \\
\hline $156 / 2005$ & 3.42 & 3.20 & 2.56 & 0.63 & 0.94 & 0.75 & 0.19 & 37 & 120 \\
\hline $184 / 2005$ & 3.36 & 3.13 & 2.52 & 0.61 & 0.93 & 0.75 & 0.18 & 34 & 116 \\
\hline $212 / 2005$ & 3.88 & 3.46 & 2.91 & 0.55 & 0.89 & 0.75 & 0.14 & 33 & 108 \\
\hline $240 / 2005$ & 4.59 & 3.55 & 3.32 & 0.23 & 0.77 & 0.73 & 0.04 & 31 & 124 \\
\hline $268 / 2005$ & 5.30 & 3.73 & 3.16 & 0.57 & 0.70 & 0.60 & 0.10 & 32 & 140 \\
\hline $302 / 2005$ & 5.58 & 3.54 & 2.47 & 1.08 & 0.64 & 0.44 & 0.20 & 32 & 163 \\
\hline Mean & 4.27 & 3.64 & 2.79 & 0.85 & 0.85 & 0.67 & 0.18 & 39 & 135 \\
\hline
\end{tabular}

determined (see Table 2). $T_{a}$ for both seasons followed the fluctuations in $E_{\mathrm{a}}$.

\subsection{Single layer crop resistances}

A more in-depth physical explanation of mango $E_{a}$ can be obtained if the aerodynamic $\left(r_{\mathrm{a}}\right)$ and bulk surface $\left(r_{\mathrm{s}}\right)$ resistances are derived. Fig. 9 shows the seasonal variation in $r_{\mathrm{a}}$ and $r_{\mathrm{s}}$ for the growing seasons of 2003-2004 (a) and 20042005 (b) calculated from $\lambda E$ measurements. The highest values of $r_{\mathrm{a}}$ coincided with the lowest values of $r_{\mathrm{s}}$ and they occurred during the rainy periods. The relatively low $r_{\mathrm{a}}$ values of approximately $35 \mathrm{~s} \mathrm{~m}^{-1}$ can be directly ascribed to the tall trees with $5.5 \mathrm{~m}$ averaged height.

The seasonal behaviour of $r_{\mathrm{s}}$ followed the dryness of the lower part of the atmosphere with some peaks associated with high values of vapour pressure deficit $(D)$ in both seasons. The value of $r_{\mathrm{s}}$ were on average $135 \mathrm{~s} \mathrm{~m}^{-1}$, which explains that the mango $E_{\mathrm{a}}$ is lower than for grass as the reference crop (for which $r_{\mathrm{s}}$ is assumed to be $70 \mathrm{~s} \mathrm{~m}^{-1}$ ). These relatively high $r_{\mathrm{s}}$ values can be ascribed to absence of a ground cover crop and the relatively dry air. Yet $r_{\mathrm{s}}$ can also vary with soil water content and soil hydraulic conductivity close to the roots.
The increase of $r_{\mathrm{s}}$ with high values of water vapour deficit (D) has been reported by Testi et al. (2006) in olive orchard in Spain. According to Rana et al. (2005), $r_{\mathrm{s}}$ is not a constant, they confirm that it varies depending on $D$, but also depends on the available energy to the crop. Alves and Pereira (2000) used the so-called climatic resistance that is directly proportional to $D$ for lettuce crop, to explain variations in $\lambda E$. If there is sufficient soil moisture to avoid water stress, conditions of high $D$ together with low values of aerodynamic resistances $\left(r_{\mathrm{a}}\right)$ promote high rates of $E_{a}$, which make the values of $r_{\mathrm{s}}$ lower and this is the case of irrigated mango orchards growing in the semi-arid conditions of São Francisco River basin. The main reasons for differences in orchard water variables between our study and some others cited above can be attributed to different species, varieties, climate, soil type, irrigation systems and frequency of irrigation, cultural management, methods of determination of evapotranspiration and also the plant density that affect the soil cover.

\subsection{Soil water balance}

Irrigated soils in the central São Francisco River basin have experienced declines in productivity, which may be a 


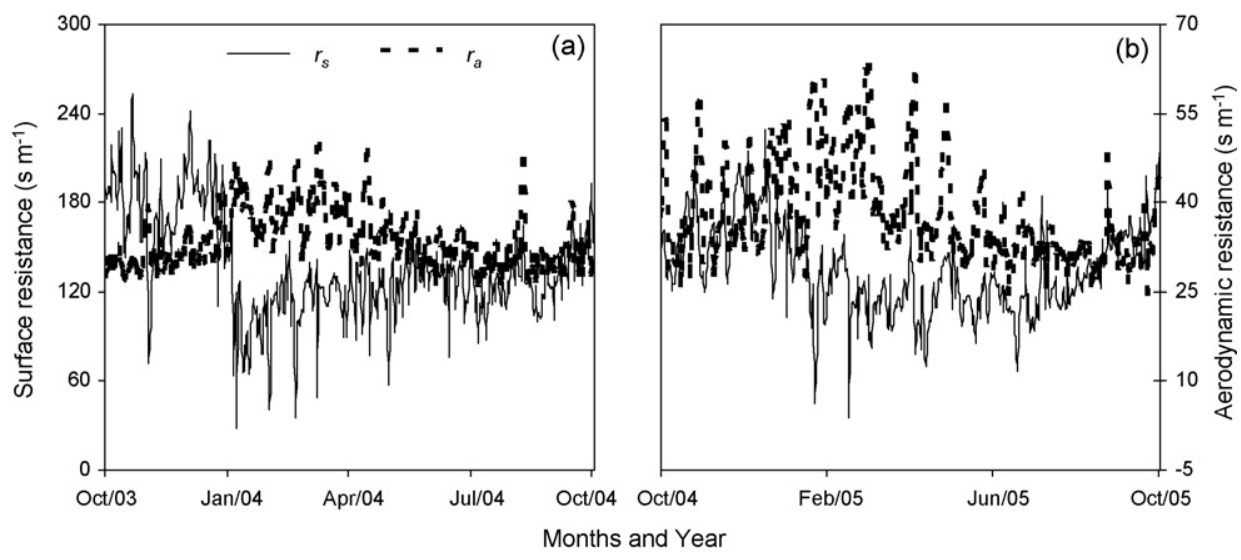

Fig. 9 - Seasonal trends of surface $\left(r_{s}\right)$ and aerodynamic $\left(r_{a}\right)$ resistances for the first (a) and the second (b) growing seasons of mango orchard.

reflection of changes in soil chemical properties due to management (Heck et al., 2003). The water flow in the unsaturated zone needs to be properly understood for assessing sustainability. The monthly soil water balance for the mango orchard is presented in Table 3, while the seasonal variation is presented in Fig. 10.

The percolation flow can be as high as $50 \mathrm{~mm}$ per week (or $200 \mathrm{~mm} \mathrm{month}^{-1}$ ) following periods of rain storms. This flow

Table 3 - Monthly soil water balance of irrigated mango trees during the first (from 060/2004 to 298/2004) and second (from 298/2004 to 291/2005) growing seasons: rainfall $(P)$; actual evapotranspiration $\left(E_{\mathrm{a}}\right)$, irrigation $(I)$, change in soil water content $(\Delta \mathrm{W})$ and deep percolation $\left(D_{P}\right)$ or capillary rise $(C P)$

\begin{tabular}{lrrrrr} 
DOY/year & \multicolumn{1}{c}{$P$} & \multicolumn{1}{c}{$E_{\mathrm{a}}$} & \multicolumn{1}{c}{$\begin{array}{c}\Delta \mathrm{W} \\
(\mathrm{mm})\end{array}$} & $\begin{array}{c}\mathrm{D}_{\mathrm{p}} \text { or } \\
(\mathrm{mm})\end{array}$ & $\begin{array}{c}\mathrm{mm}) \\
(\mathrm{mm}) \\
\mathrm{CP}(\mathrm{mm})\end{array}$ \\
\hline GS1 & & & & & \\
060/2004-091/2004 & 76.2 & 128.1 & 0.0 & 19.3 & 32.5 \\
092/2004-121/2004 & 20.8 & 125.7 & 0.0 & 32.1 & 72.7 \\
122/2004-152/2004 & 19.6 & 107.1 & 29.4 & -28.9 & 29.2 \\
153/2004-182/2004 & 0.0 & 97.8 & 104.4 & -2.5 & -9.1 \\
183/2004-213/2004 & 0.3 & 102.2 & 112.7 & -0.2 & -11.0 \\
214/2004-244/2004 & 0.5 & 114.7 & 122.9 & -1.7 & -10.3 \\
245/2004-274/2004 & 0.0 & 141.4 & 118.2 & 8.1 & 15.2 \\
275/2004-298/2004 & 0.0 & 108.9 & 121.0 & 4.9 & -17.0 \\
Total & 117.4 & 925.9 & 608.6 & 31.1 & 102.2 \\
& & & & & \\
GS2 & & & & & \\
299/2004-335/2004 & 22.1 & 157.3 & 137.0 & 10.2 & -12.0 \\
336/2004-366/2004 & 0.0 & 125.7 & 104.8 & 11.0 & 9.9 \\
001/2005-031/2005 & 31.5 & 116.2 & 127.5 & 12.7 & -55.5 \\
032/2005-059/2005 & 153.7 & 103.2 & 120.5 & -24.8 & -195.7 \\
060/2005-090/2005 & 96.0 & 115.2 & 71.8 & 1.5 & -54.2 \\
091/2005-120/2005 & 23.9 & 110.7 & 0.0 & 9.7 & 77.0 \\
121/2005-151/2005 & 24.9 & 92.9 & 0.0 & 0.7 & 67.2 \\
152/2005-181/2005 & 15.2 & 94.8 & 80.5 & 4.6 & -5.6 \\
182/2005-212/2005 & 3.0 & 105.8 & 112.5 & -28.3 & -38.0 \\
213/2005-243/2005 & 7.4 & 110.5 & 128.7 & 5.1 & -30.6 \\
244/2005-273/2005 & 0.0 & 111.3 & 117.2 & 2.7 & -8.7 \\
274/2005-291/2005 & 4.1 & 63.6 & 81.3 & -3.5 & -25.2 \\
Total & 381.8 & 1307.2 & 1081.8 & 1.6 & -271.4 \\
\hline
\end{tabular}

can be regarded as happening at a depth of $140 \mathrm{~cm}$ below natural ground surface. The largest fluctuations in percolation are found during the rainy season (see Fig. 10b). The highly permeable soils have a great drainage capacity that ensures that soil moisture is not rising and that excessive moisture percolates downwards. This is in agreement with the general soil water requirements of mango orchard; hence it has been a good choice to cultivate this fruit crop in the soils and climate of Petrolina-PE. The latter is confirmed from the soil moisture changes. Table 3 shows that the changes across a month are $30 \mathrm{~mm}$ at maximum.

The soil water balance as defined in Eq. (5) could be computed only for the period in which soil moisture of the layers and $E_{\mathrm{a}}$ were measured. The percolation flows are rather conserved during the irrigation season and outside the rainy season. During dry periods, the measurements suggest that capillary rise provided extra water to the root zone. This last process can be established only if the $120 \mathrm{~cm}$ deep moisture layer is wetter that the $100 \mathrm{~cm}$ layer. This indeed sometimes occurred, especially after the end of the rainy period during the first growing season, when the time without irrigation during this period was longer than in the second season (see Figs. 3 and 10).

Seasonal percolation could be computed as being around $300 \mathrm{~mm}$, considering the rate of $0.8 \mathrm{~mm} \mathrm{day}^{-1}$, from the data during the second growing season (Table 3), and a mean duration for the two seasons of 380 days. This is a substantial return flow of the irrigation system that to a large degree is manageable. Irrigation conservation could reduce the percolation. An example of stress induced soil water content is described in Nadler et al. (2006). The limited distance of $5.5 \mathrm{~km}$ from the river ensures that most return flow is drained to the São Francisco. The significant percolation flow transports the solutes down to the groundwater. Both groundwater quality and the soil health need to be controlled.

\subsection{Irrigation performance and crop water productivity}

Knowledge of the water balance allows the evaluation of irrigation performance and water productivity. Irrigation performance has been introduced to describe the hydrological 


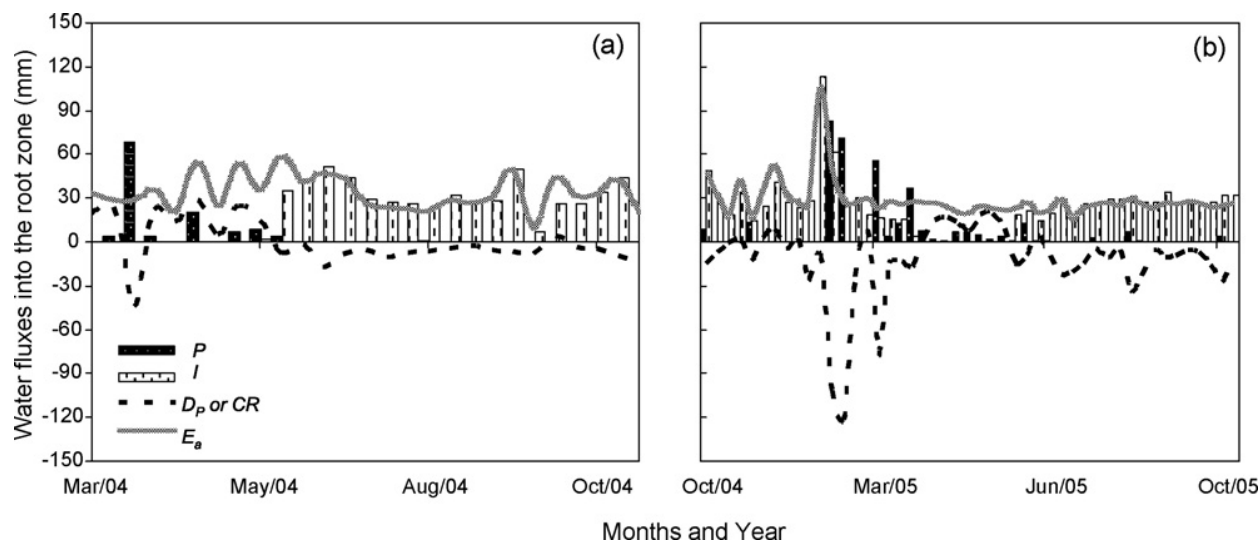

Fig. 10 - Soil water balance into the root zone for the first (a) and second (b) growing seasons in mango orchard: precipitation $(P)$; irrigation (I); deep percolation $\left(D_{P}\right)$; capillary rise $(C R)$ and actual evapotranspiration $\left(E_{a}\right)$.

behaviour of irrigation systems by means of simple understandable ratios, which involve agro-meteorological data, water delivered and water consumed (Bos et al., 2005).

The crop water productivity indicators are summarized in Tables 4 and 5 according to the crop stages and growing seasons. The water indicator $R_{\mathrm{Ws}}$ found for the mango orchard showed the presence of a gap between crop water demands and supply for some crop stages, which was more pronounced during the first growing season. The main reason could be due to irrigation management during the rainy period. The farmer stopped the irrigation at crop stages between branch development and flowering which coincided with the rainy period for both seasons. The time without irrigation in the first season was longer than during the second. For the first season the values of $R_{\mathrm{Ws}}$ were in the range from 0.41 to 1.45 and for second they were in the range from 0.86 to 1.21 . The indicator $C_{\text {WD }}$ showed some deficit during branch development-flowering stages, having totals of 73-95 $\mathrm{mm}$ for the first and second growing seasons, respectively, evidence of a very low water shortage, that agrees with the finding of a constant wetted root zone.

The eddy covariance measurements yielded mean $R_{\mathrm{Ws}}$ of 1.13 and 1.05 for the first and second growing seasons. In general $R_{\mathrm{Ws}}$ greater than one could be taken as an advantage from the point of view of securing the crop water requirements as well as groundwater recharge. These numbers imply that approximately $10 \%$ more irrigation water was supplied than was necessary to meet the crop water requirements. This is according to best practice as some of the irrigation water will unavoidably leak away from the orchard. The optimum value for relative water supply would be 0.80 , because $C_{\mathrm{WP}}$ increases with water stress. This case study showed that for the period vegetative growth-branch development of mango growing seasons, more water should be saved from reduced supplies, while care should be taken after the rainy period where more water should be given as the water quickly percolates away. A

Table 4 - Actual $\left(E_{\mathrm{a}}\right)$ and potential $\left(E_{\mathrm{p}}\right)$ evapotranspiration, crop water deficit $\left(C_{\mathrm{WD}}\right)$, rainfall $(P)$, irrigation (I) and relative water supply $\left(R_{\mathrm{wS}}\right)$, during the phenological phases of the mango orchard

\begin{tabular}{|c|c|c|c|c|c|c|c|}
\hline Phase & Period & $E_{\mathrm{a}}(\mathrm{mm})$ & $E_{p}(m m)$ & $\mathrm{C}_{\mathrm{WD}}(\mathrm{mm})$ & $P(\mathrm{~mm})$ & $\mathrm{I}(\mathrm{mm})$ & $R_{W S}$ \\
\hline \multicolumn{8}{|l|}{ GS1 } \\
\hline Previous post-harvest & 1-31 October 2003 & 106 & 111 & 5 & 0 & 99 & 0.89 \\
\hline Vegetative growth & 01-30 November 2003 & 116 & 121 & 4 & 36 & 95 & 1.08 \\
\hline Branch development & 01 December 2003 to 30 April 2004 & 597 & 623 & 26 & 831 & 74 & 1.45 \\
\hline Flowering & 01-31 May 2004 & 107 & 113 & 6 & 20 & 27 & 0.41 \\
\hline Fruit initiation & 01-30 June 2004 & 98 & 109 & 11 & 0 & 104 & 0.96 \\
\hline Fruit growth & 01-31 July 2004 & 102 & 110 & 8 & 0 & 113 & 1.02 \\
\hline Fruit maturation & 01-31 August 2004 & 115 & 123 & 8 & 1 & 123 & 1.00 \\
\hline Harvest & 01 September 2004 to 24 October 2004 & 250 & 254 & 4 & 0 & 239 & 0.94 \\
\hline Season & 01 October 2003 to 24 October 2004 & 1492 & 1565 & 73 & 887 & 874 & 1.13 \\
\hline \multicolumn{8}{|l|}{ GS2 } \\
\hline Previous post-harvest & 25 October 2004 to 31 December 2004 & 283 & 305 & 22 & 22 & 242 & 0.86 \\
\hline Vegetative growth & 01-31 January 2005 & 116 & 136 & 20 & 32 & 127 & 1.17 \\
\hline Branch development & 01 February 2005 to 31 May 2005 & 422 & 445 & 23 & 298 & 192 & 1.10 \\
\hline Flowering & 01 June 2005 to 03 July 2005 & 104 & 110 & 6 & 15 & 90 & 0.96 \\
\hline Fruit initiation & 04-24 July 2005 & 67 & 71 & 4 & 0 & 76 & 1.08 \\
\hline Fruit growth & 25 July 2005 to 25 August 2005 & 118 & 125 & 7 & 7 & 129. & 1.09 \\
\hline Fruit maturation & 26 August 2005 to 24 September 2005 & 112 & 118 & 7 & 0 & 116 & 0.98 \\
\hline Harvest & 25 September 2005 to 29 October 2005 & 124 & 130 & 6 & 6 & 152 & 1.21 \\
\hline Season & 01 November 2004 to October 2005 & 1346 & 1441 & 95 & 380 & 1126 & 1.05 \\
\hline
\end{tabular}


Table 5 - Yield (kilograms of fruits) and crop water productivity ( $C_{\mathrm{WP}}$ ) based on cultivated land (L), irrigation (I), actual

evapotranspiration $\left(E_{a}\right)$ and actual transpiration $\left(T_{a}\right)$ of mango orchard, together with economic values of these indices ( $\$$ )

\begin{tabular}{|c|c|c|c|c|c|c|c|c|c|}
\hline GS & $\begin{array}{c}\text { Yield } \\
\text { (tonnes) }\end{array}$ & $\begin{array}{c}C_{\mathrm{WP}_{\mathrm{L}}} \\
\left(\mathrm{kg} \mathrm{ha}^{-1}\right)\end{array}$ & $\begin{array}{c}\mathrm{CWP}_{\mathrm{I}} \\
\left(\mathrm{Kg} \mathrm{m}^{-3}\right)\end{array}$ & $\begin{array}{c}\mathrm{CWP}_{\mathrm{Ea}_{\mathrm{a}}} \\
\left(\mathrm{Kg} \mathrm{m}^{-3}\right)\end{array}$ & $\begin{array}{c}\mathrm{CWP}_{\mathrm{Ta}_{\mathrm{a}}} \\
\left(\mathrm{Kg} \mathrm{m}^{-3}\right)\end{array}$ & $\begin{array}{c}\mathrm{CWP}_{\mathrm{W}} \\
\left(\mathrm{US} \$ \mathrm{ha}^{-1}\right)\end{array}$ & $\begin{array}{c}\mathrm{CWP}_{\mathrm{WP}} \\
\left(\mathrm{US} \$ \mathrm{~m}^{-3}\right)\end{array}$ & $\begin{array}{c}\mathrm{C}_{\mathrm{WPS} S_{\mathrm{E}_{\mathrm{a}}}} \mathrm{CWPS}_{\mathrm{W}_{\mathrm{a}}} \\
\left(\mathrm{US} \$ \mathrm{~m}^{-3}\right)\end{array}$ & $\begin{array}{c}\mathrm{CWP}_{\mathrm{Wa}} \\
\left(\mathrm{US} \$ \mathrm{~m}^{-3}\right)\end{array}$ \\
\hline GS1 & 496 & 41,593 & 4.8 & 2.8 & 3.6 & 42,425 & 4.9 & 2.9 & 3.7 \\
\hline GS2 & 577 & 48,405 & 4.3 & 3.6 & 5.4 & 49,373 & 4.4 & 3.7 & 5.5 \\
\hline
\end{tabular}

reduction of irrigation water in April to July will also reduce the drainage effluents and prevent nutrients and chemical leaching away from the root zone. Table 4 shows that the second growing season had a very constant and ideal $R_{W s}$ value around 1.0. The irrigation was less during the rainy season and much higher during the dry season from July to October. During the first growing season, irrigation management could have been much better: there was over-irrigation during branch development and under-irrigation during flowering. It is interesting to study the impact of water stress during flowering on the final fruit yield.

Mango yields vary with the cultivar and the age of the tree. A well-managed orchard may yield 200-300 fruits per tree. Old trees in Java are known to produce 1000-1500 fruits per tree. In Puerto Rico, mango yield varies among 29-67 tonne ha ${ }^{-1}$ (Morton, 1987). The average mango yield in Florida is 30 tonne ha ${ }^{-1}$. The statistical average mango yield in Petrolina during 1998 was 20.8 tonne ha ${ }^{-1}$. The mango yields in our investigation $\left(C_{\mathrm{WP}_{\mathrm{L}}}\right)$ were 41.6 and 48.4 tonne ha ${ }^{-1}$ for the first and second growing season, respectively. This difference between the two growing seasons can likely be ascribed to the water stress during flowering in the first growing season.

According to the growing seasons, the $C_{\mathrm{WP}_{\mathrm{I}}}$ values were 4.76 and $4.30 \mathrm{~kg} \mathrm{~m}^{-3}$ and the $C_{\mathrm{WP}_{\mathrm{Ea}}}$, values were 2.79 and $3.60 \mathrm{~kg} \mathrm{~m}^{-3}$. When the crop water productivity was analyzed based on actual transpiration only following plant physiological mechanisms, $C_{\mathrm{WP}_{\mathrm{Ta}}}$ values were 3.57 and $5.38 \mathrm{~kg} \mathrm{~m}^{-3}$. This type of bio-physical water productivities are generally higher than for arable crops (essentially $C_{\mathrm{WP}_{\mathrm{E}_{\mathrm{a}}}}$ from 0.5 to $1.5 \mathrm{~kg} \mathrm{~m}^{-3}$ for wheat and rice; see Zwart and Bastiaassen, 2004) but comparable to grapes $\left(\mathrm{CWP}_{\mathrm{E}_{\mathrm{a}}}\right.$ is $3.8 \mathrm{~kg} \mathrm{~m}^{-3}$; Teixeira et al., 2007) that both contain a high moisture content of the fresh product (approximately $75-80 \%$ ).

The monetary component of crop water productivity $\left(C_{\mathrm{WP} \$}\right)$ was also computed per unit irrigation $\left(\mathrm{C}_{\mathrm{WP} \$_{\mathrm{I}}}\right)$, actual evapotranspiration $\left(\mathrm{C}_{\mathrm{WPS}_{\mathrm{E}_{\mathrm{a}}}}\right)$ and actual transpiration $\left(\mathrm{CWP}_{\mathrm{WP}_{\mathrm{a}}}\right)$. The

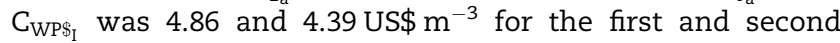
growing seasons, respectively. In relation to $C_{\mathrm{WP}_{\mathrm{E}_{\mathrm{a}}}}$ the values were 2.85 and $3.68 \mathrm{US} \$ \mathrm{~m}^{-3}$. For transpiration, the $\mathrm{C}_{\mathrm{WP} \Phi_{\mathrm{T}}}$ was 3.65 and 5.50 US $\$ \mathrm{~m}^{-3}$ (see Table 5).

An economic water productivity of 3-4 US\$ $\mathrm{m}^{-3}$ per unit of water depleted is almost a factor 20 more than for irrigated staple crops. The agricultural water usage in the semi-arid region of São Francisco river basin is thus highly productive, besides also providing jobs in the agri-business, which is a stimulus for rural development of the region.

\section{Conclusions}

Because of the importance of the water management in fruit crops, daily and seasonal water-use patterns of a large commercial mango orchard were collected. The results presented in this paper are important for irrigation management, water allocation, water savings and environmental sustainability of irrigated mango orchards.

Despite the aerodynamically rough surface with the crowns of mango trees exceeding $5 \mathrm{~m}$, the actual ET of the mango orchard is less than for grass as a reference crop $\left(k_{c}=0.91\right)$. The underlying reason is the presence of a relatively large bulk surface resistance $\left(135 \mathrm{~s} \mathrm{~m}^{-1}\right)$ due to presence of older leaves, shadow in the crown, distance between trees for mechanical access and the absence of a ground cover crop.

In the commercial farm investigated, soil moisture, evaporative fraction, crop water deficit and relative water supply were kept at ideal levels, especially considering the values for the entire growing seasons. The drawback of a wet light textured soil is the capacity to percolate excessive water resources. The annual percolation flow was $300 \mathrm{~mm}$, and this is a threat to groundwater contamination and soil salinity build up, if drainage is not given proper attention.

The bio-physical and economical water productivities of mango are very high. An economic water productivity of US\$ $2.90-3.70 \mathrm{~m}^{-3}$ is an order of magnitude better than for staple crops. Hence from a scarce water resources point of view, water allocation to irrigated mango orchards is desirable. Although this water usage is highly productive, the environmental consequences must be considered keeping irrigated horticulture in pace with sustainability requirements. The challenge is to find a balance between water productivity and environmental pollution.

\section{Acknowledgements}

The research herein was supported by CAPES (Ministry of Education, Brazil), Embrapa (Brazilian Agricultural Research Corporation) and International Water Management Institute (IWMI). The Department of Meteorology of Wageningen University and Research Centre (WUR) is acknowledged for screening of raw eddy covariance data.

\section{R E F E R E N C E S}

Allen, R.G., Pereira, L.S., Raes, D., Smith, M., 1998. Crop Evapotranspiration. Guidelines for Computing Crop Water Requirements. FAO Irrigation and Drainage Paper 56. Rome, Italy, $300 \mathrm{pp}$.

Alves, I., Pereira, L.S., 2000. Modelling surface resistance from climatic variables. Agric. Water Manage. 42, 371-385.

Azevedo, P.V., Silva, B.B., da Silva, V.P.R., 2003. Water requirements of irrigated mango orchards in northeast Brazil. Agric. Water Manage. 58, 241-254. 
Bastiaanssen, W.G.M., Brito, R.A.L., Bos, M.G., Souza, R.A., Cavalcanti, E.B., Bakker, M.M., 2001. Low cost satellite data for monthly irrigation performance monitoring: benchmarks from Nilo Coelho, Brazil. Irrig. Drain. Syst. 15, 53-79.

Bos, M.G., Burton, M.A., Molden, D.J., 2005. Performance indicators for irrigation and drainage. In: Irrigation and Drainage Performance Assessment. Practical Guidelines, CABI Publishing, pp. 26-61.

Businger, J.A., Wyngaard, J.C., Izumi, Y., Bradley, E.F., 1971. Fluxprofile relationships in the atmospheric surface layer. J. Atmos. Sci. 28, 189-191.

Chehbouni, A., Ezzahar, J., Watts, C., Rodriguez, J.-C., GaratuzaPayan, J., 2006. Estimating area-averaged surface fluxes over contrasted agricultural patchwork in a semi-arid region. In: Hill, J., Roder, A. (Eds.), Advances in Remote Sensing and Geoinformation Processing for Land Degradation Assessment. Taylor and Francis.

Heck, R.J., Tiessen, H., Salcedo, I.H., Santos, M.C., 2003. Soil chemical changes under irrigated mango production in the central San Franciso River valley, Brazil. J. Environ. Qual. 32, 1414-1421.

Heilman, J.L., Mcinnes, K.J., Gesh, R.W., Lascano, R.J., Savage, M.J., 1996. Effects of trellising on the energy balance of the vineyard. Agric. For. Meteorol. 81, 79-93.

Hoedjes, J.C.B., Zuurbier, R.M., Watts, C.J., 2002. Large aperture scintillometer used over a homogeneous irrigated area, partly affected by regional advection. Bound.-Lay. Meteorol. 105, 99-117.

Lopes, P.M.O., Silva, B.B.da., Azevedo, P.V.de, Silva, V.P.da.R., Teixeira, A.H.C., Soares, J.M., Sobrinho, J.E., 2001. Balanço de energia num pomar de mangueiras irrigado. Rev. Bras. Agrometeorol. 9, 1-8.

Molden, D., Murray-Rust, H., Sakthivadivel, R., Makin, I., 2003. A water-productivity framework for understanding and action CABI. In: Kijne, J.W., Barker, R., Molden, D. (Eds.), Water Productivity in Agriculture: Limits and Opportunities for Improvement. Chapter 1. pp. 1-18.

Molle, F., Sutthi, C., Keawkulaya, J., Korpraditskul, R., 1999. Water management in raised bed systems: a case study from the Chao Phraya delta, Thailand. Agric. Water Manage. 39, 1-17.

Moore, C.J., 1986. Frequency response corrections for eddy correlation systems. Bound.-Lay. Meteorol. 37, 17-35.

Morton, J.F., 1987. In: Morton, J.F. (Ed.), Fruits of warm climates. Miami, Florida, pp. 221-239.

Mostert, P.G., Wantenaar, L., 1994. Water needs and irrigation of mature mango trees. S.A. Mango Growers'Assoc. Yearbook $14,21-23$.

Nadler, A., Raveh, E., Yermiyahu, U., Green, S., 2006. Stress induced water content variations in mango stem by time domain reflectometry. Soil Sci. Soc. Am. J. 70, 510-520.

Paço, T.A., Ferreira, M.I., Conceição, N., 2006. Peach orchard evapotranspiration in a sandy soil: comparison between eddy covariance measurements and estimates by the FAO 56 approach. Agric. Water Manage. 85 (3), 305-313.

Paw, U.K.T., Baldocchi, D.D., Meyers, T.P., Wilson, K.B., 2000. Corrections of eddy covariance measurements incorporating both advective effects and density fluxes. Bound.-Lay. Meteorol. 97, 487-511.
Rana, G., Katerji, N., Lorenza, F.de., 2005. Measuring and modelling of evapotranspiration of irrigated citrus orchard under Mediterranean conditions. Agric. For. Meteorol. 128, 199-209.

Sammis, T.W., Mexal, J.G., Miller, D., 2004. Evapotranspiration of flood-irrigated pecans. Agric. Water Manage. 69, 179-190.

Scott, C.A., Bastiaanssen, W.G.M., Ahmad, M.D., 2003. Mapping root zone soil moisture using remotely sensed optical imagery. ASCE J. Irrig. Drain. Eng. 129, 326-335.

Simmons, L.J., Wang, J., Sammis, T.W., Miller, D.R., 2007. An evaluation of two inexpensive energy-balance techniques for measuring water use in flood-irrigated pecans. Agric. Water Manage. 88, 181-191.

Tanner, B.D., Swiatek, E., Greene, J.P., 1993. Density fluctuations and use of the krypton hygrometer in surface flux measurements. In: Proceedings of the National Irrigation Drainage Engineering. Park City, UT, 21-23 July 1993, ASCE, New York, NY.

Teixeira, A.H., de, C., Bastiaanssen, W.G.M., Bassoi, L.H., 2007. Crop water parameters of irrigated wine and table grapes to support water productivity analysis in Sao Francisco river basin Brazil. Agric. Water Manage. 94, 31-42.

Testi, L., Villalobos, F.J., Orgaz, F., 2004. Evapotranspiration of a young olive orchard in southern Spain. Agric. For. Meteorol. 121, 1-18.

Testi, L., Orgaz, F., Villalobos, F.J., 2006. Variations in bulk canopy conductance of an irrigated olive (Olea europaea L.) orchard. Environ. Exp. Bot. 55, 15-28.

Twine, T.E., Kustas, W.P., Norman, J.M., Cook, D.R., Houser, P.R., Meyers, T.P., Prueger, J.H., Starks, P.J., Wesely, M.L., 2000. Correcting eddy-covariance flux estimates over grassland. Agric. For. Meteorol. 103, 279-300.

Van Dijk, A., Moene, A.F., de Bruin, H.A.R., 2004. The principles of surface flux physics: theory, practice and description of the Ecpack library. Internal Report. Meteorology and Air Quality Group, Wageningen University, Wageningen, The Netherlands, 99 pp.

Vilalolobos, F.J., Testi, L., Rizzalli, R., Orgaz, F., 2004. Evapotranspiration and crop coefficients of irrigated garlic (Allium sativum L) in a semi-arid climate. Agric. Water Manage. 64, 233-249.

Webb, E.K., Pearmen, G.L., Leuning, R., 1980. Correction of flux measurements for density effects due to heat and water vapour transfer. Q. J. Roy. Meteorol. Soc. 106, 85-100.

Williams, L.E., Ayars, J.E., 2005. Grapevine water use and the crop coefficient are linear functions of the shaded area measured beneath the canopy. Agric. For. Meteorol. 132, 201-211.

Wilson, K., Goldstein, A., Falge, E., Aubinet, M., Baldocchi, D., Berbigier, P., Bernhofer, C., Ceulemans, R., Dolman, H., Field, C., Grelle, A., Ibrom, A., Law, B.E., Kowalski, A., Meyers, T., Moncrieff, J., Monson, R., Oechel, W., Tenhunen, J., Valentini, R., Verma, S., 2002. Energy balance closure at Fluxnet sites. Agric. For. Meteorol. 113, 223-243.

Yunusa, I.A.M., Walker, R.R., Lu, P., 2004. Evapotranspiration components from energy balance, sapflow and microlysimetry techniques for an irrigated vineyard in inland Australia. Agric. For. Meteorol. 127, 93-107.

Zwart, S.J., Bastiaassen, W.G.M., 2004. Review of measured crop water productivity values for irrigated wheat, rice, cotton and maize. Agric. Water Manage. 69, 115-153. 